\title{
里地保全に関連する市町村条例の類型化に関する考察
}

\section{A Study on the Classification of Municipal Ordinances Regarding Satochi Landscapes Conservation}

\author{
三瓶 由紀* 武内 和彦* \\ Yuki SAMPEI Kazuhiko TAKEUCHI
}

\begin{abstract}
Recently, municipal ordinances regarding Satochi landscapes conservation have been frequently enacted, and expectations for these ordinances have been increasing. Improvement of the implementation of these municipal ordinances can be regarded as urgent and important. As a first step toward improvement, this paper attempts to give a detailed picture of these ordinances at regional scale by classification based on the contents of the documents of in these ordinances. As a result, three different types were distinguished. The first type consisted of ordinances enacted recently, in which a target site with farmland and forest and the community participation system as implementation measure were described (Type A). It was considered that this type of ordinance responded to the problems on conserving farmland and forest integrally. The second type consisted of ordinances in which government-initiated implementation measures regarding the maintenance of forests or agricultural lands were described (Type B). The third type consisted of ordinances without a definite description of the target site and implementation measures (Type C). It was also suggested that ordinances of Type A and Type B had different institutional issues. It was considered that Type A and Type B contributed to different aspect of Satochi landscape conservation and that a resolution of issues of each type was needed.
\end{abstract}

Keywords: Satochi landscapes, Municipal ordinance, Secondary nature conservation キーワード：里地，市町村条例，二次的自然環境保全

\section{1.はじめに}

近年, 自然環境への関心が高まり, 身近な自然とのふれあいの 場として, また豊かな生活に欠かせない要素として, 里地が再評 価されている1)。

里地は，里山・農地・集落などの複数の土地利用が相互に関係 する, 人間の自然への働きかけにより維持されてきた空間であ $ろ^{2)}$ 。しかし高度成長期以降, 特に都市農村混在地域において, 市街化による里地・里山の減少が進行してきた。また, 農家の担 い手の減少に伴う管理放棄もみられるなど，さまざまな土地利用 上の問題が生じている ${ }^{3)}$ 。里地の保全は早急に対応が求められる 課題であり, なかでも土地利用調整に関する制度的支援の具体化 は非常に重要であると考えられる。

これまでわが国における土地利用調整は, 主として個別規制法 により実施されてきた。これらの法律は, 農地や森林を含めた総 合的な計画を制度として規定しておらず，原則として各々の土地 利用に即した行政的な対応がなされる。そのため, 里地を全体と して保全する場合には適応が困難であることが指摘されてきた このような問題に対応しうるものとして市町村による独自の条例 への期待が高まりをみせている。多くの自治体において, 二次的 自然や二次的自然景観の保全を目的とした条例が制定され始めた。 地方分権が推進される現在, 市町村条例による里地保全制度の重 要性は大きくなると考えられ, その実効性を評価し改善を図るこ とが求められる。そのためにはまず, 既存条例の制定動向や実態 を把握し, それらに規定される制度の課題点を明らかにすること が必要とされる。

条例の実態把握は，これまでもいくつかの研究において，類型 化等の手法を通じて試みられてきているが5(5)77)8, 多様な内容を 規定していること，さらに定義も不明瞭であることから，包括的・ 定量的な分析を行った研究は少なく ${ }^{8)}$, 里地保全に関連する市町 村条例について扱ったものはない。

里地の保全においては, 土地の確保之管理の両面からの配慮に
加え, 里山や農地を単独に扱うのではなく, 里地全体をひとつの 区域として一体的にとらえることが重要な課題である ${ }^{1)}$ 。里地保 全に関連する条例はこのような課題に，目的や保全対象，実現の ための手法（以下あわせて戦略と称す）の規定により，それぞれ に地域の目指すべき目標を具体化することで, 対応していると想 定される。

そこで本研究では，条例に規定される戦略に焦点をあて，関東 南部の里地保全に関連する条例について, 規定内容の数量化によ り定量的な類型化を試みる。その上で，各類型について活用実態 の検証を通じて, 既存条例の評価・改善の検討するための基礎的 知見を得ることを目的とした。

\section{2. 研究の対象と方法}

\section{(1) 調查対象地}

調查対象地域として, 関東南部の 1 都 4 県（東京, 埼玉, 千葉, 神奈川, 茨城) を選択した。これらの地域は里地里山が残存しつ つも消失の危機に直面しているとされており，比較的早期から， 市町村条例による緑地等の保全がはかられてきた地域でもある ${ }^{9)} 。$ （2）使用データ

里地は二次的自然を打もな構成要素としていることは広く認識 されている。また里地は, 里山, 農地, 農村集落等が一体となっ て形成していた二次的自然景観である ${ }^{11}$ 。そこで本研究では, 前 文・目的・基本理念において，二次的自然あるいは二次的自然景 観（以下あわせて二次的自然環境亡する）の保全に関する規定が みられた条例を対象として, 分析を行った ${ }^{10)}$ 。

条例の条文は, 2005 年 7 月末までに各自治体の公式 web サイ トで公開された例規集より収集した。1975 年から 2005 年までに 制定された 37 市町村から 40 条例が収集された。

また，各条例による特定区域の指定状況は，2005 年の 8 月に 各市町村への電話による問い合わせ形式でヒアリングを行い, 7 月末時点での指定箇所数およびそれらの名称，全改正の背景など

"東京大学大学院農学生命科学研究科 


\section{(3) 研究の方法}

研究方法は, 第一に, 里地保全に関連す る条例に，どのような戦略が規定されてい るのか, その傾向をとらえるため, 類型分 析を行う。具体的には，まず条例を概観し 規定内容を把握するための項目の整理を行 い，整理された各項目についての規定状況 を把握する。次に, その結果に基づき規定内容を数量 化し, 類型化を行う。

第二に, 得られた類型化の結果にもとづき, 具体的 な担保手法を規定し, 比較的有効性が高い類型 A と Bについて, その制定動向と活用実態を検証した（類 型結果は 3 に示す)。

\section{3. 規定内容に基づく対象条例の類型化}

\section{(1) 規定内容の把握}

\section{(i ) 項目の整理}

里地の保全という視点からみた場合, 条例の規定内 容は, 大きく, 1 ) 目的・基本理念，2）基本的事項, 3 ）担保手法, に区分され，それぞれにおいて里地の 保全に関連する内容が規定されている ${ }^{11)}$ 。したがって,

表一2 里地保全に関連する条例において規定されていた担保手法の種類

本論における類型根拠は, 条文に規定される目的, 保全対象, 担 保手法に求めることとした。なお，ひとつの条例において複数の 特定区域が設定され, それぞれ異なる保全対象や担保手段が規定 されている場合があるが，本論では二次的自然環境に関連する区 域を代表として解析に使用した ${ }^{1213}$ 。

\section{（ii）各項目の規定状況}

既往研究 ${ }^{8) 11}$ を参考に, 目的では自然環境保全, 生活環境保全, 景観保全，まちづくり，の 4 項目が確認された（表－1）。また， 保全対象については，1）樹林地，2）農地，3)樹林地および農地を 含みうる一定の区域を指定できる旨が明示されている区域（以下 一体的区域)，4）規定なしの 4 つの項目が確認され (表 -1 ), 担 保手法では 10 項目が抽出された（表一 2)。

\section{(ii）各項目に関する規定状況}

表一 3 にそれぞれの項目，またはその組み合わせに応じた条例 数を示す。これによると, 目的では, 組み合わせパターンは 7 種 類確認され，13 条例において複数項目の組み合わせが規定され ていた。担保手法の組み合わせパターンは，規定なしも含めて 13 種類確認され，19 条例において複数項目の組み合わせが規定 されていた。

\section{(2) 条例の類型分析}

(i) 分析方法

規定状況の把握により示された組み合わせは条例の特性を示す と考えられる。そこで本論では, 40 サンプルの条例について, 表一 1 に示す 17 項目をダミ一変数とし, 規定が存在する場合を 1 , 存在しない場合を 0 として值を与え，デー夕を作成した。 これらのデー夕に基づき, 数量化正類とよばれる手法を用いて,

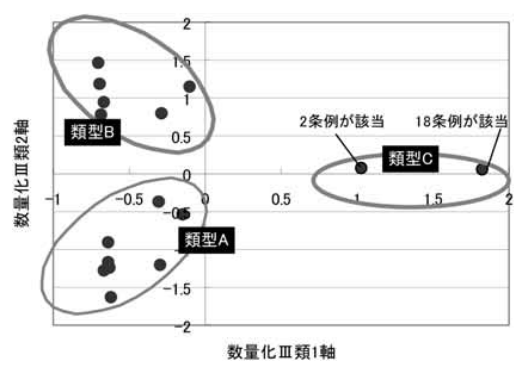

図-1＼cjkstart規定内容の数量化による条例の類型結果
各条例の数量化を行っ た。この過程で, 項 目の規定状況の類似 性がデー夕に反映さ れる。すなわち, 同 じ項目を規定してい る条例には同じ值を 与えられ, 類似した 項目が規定されてい る条例には近い数值 


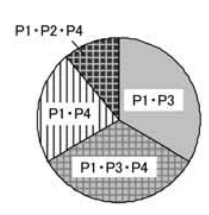

類型 $\mathrm{A}$

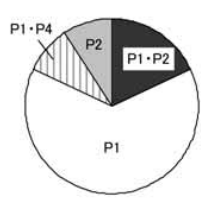

類型 $\mathrm{B}$

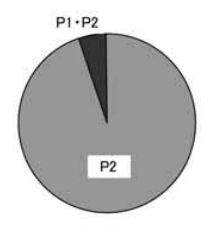

類型 $\mathrm{C}$

図-3 類型ごとの目的の規定状況

表 -4 類型別にみた担保手法項目の 組み合わせ規定状況 (単位: 条例数)

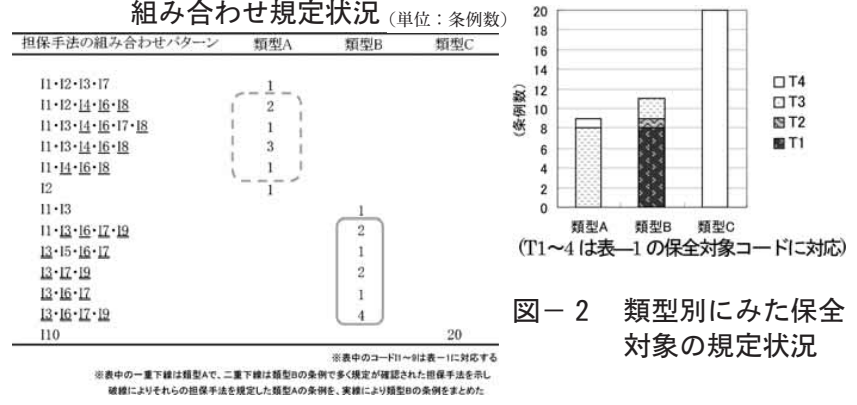

特性を有する。これらの条例では樹林地のみを対象とする条例が 多く (図-3), 区域の一体的な保全という課題には対応出来な い可能性があるため, 周辺の農地との関連性の維持をはかるシス テムが求められると考えられた。

類型 C は, 具体的な対象や担保を規定しない, 啓発的な役割 をもつ特性を有すると考えられた。

\section{4. 各類型の制定動向と活用の実態}

\section{(1) 検証項目}

動向については制定年 ${ }^{14)} に よ り$ 把握し, 活用の実態については これらの条例が特定区域を規定している点に特徴付けられる（表一 4 ) ことから, 特定区域の指定状況, 指定箇所数により把握する。 全域についての制度は条例が改正されない限り継続するが, 特定 区域, 特に地域性緑地に関しては指定が一定の期間に限られ, 担 保の有効性が維持されない場合があり, 指定期間の継続性は保全 の実現性において, 重要な要素といえる。そこで指定の継続性に ついても，どのような方針が規定されているか把握した。

(2) 結果と考察

(i ) 類型 $\mathrm{A}$

制定時期について確認したところ，9 条例のうち 7 条例が 2000 年以降に制定される新しい条例であることが示された（図－4）。 類型 A においてみられるような, 地域住民による計画策定の手 法, いわゆる住民参加型の手法は, 最近制定される傾向にあるこ とが指摘されている ${ }^{6 / 8)}$ 。里地保全においても，民意を反映した 計画的な視点から保全に取組むシステムの導入がなされてきてい ることが伺われた。

しかし，一方で実際にどれくらいの区域が，これらの条例に基 づいて指定されているかを確認したところ, 類型 $\mathrm{A}$ の条例では 実際に特定区域の指定が行われていた条例は, 9 条例のうち 3 条

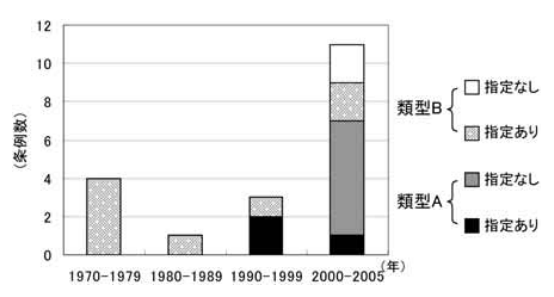

図一 4 類型 $A \cdot B$ の条例における特定 区域の制定時期別指定状況

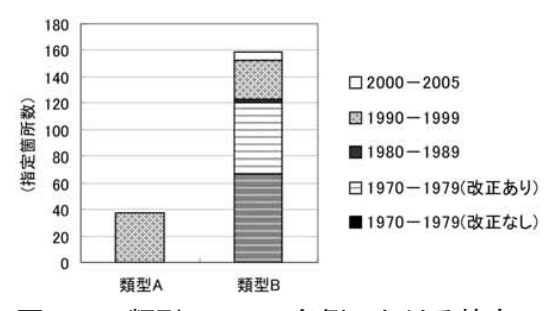

図一 5 類型 $A$ ・B の条例における特定 区域の制定時期別指定箇所数
例でしかなかった（図－4）。このうち 2 条例は 1990 年代に制定 された条例である（これらの 2 条例のうち 1 条例は住民活動の認 定を規定するものではなく，行政主導の土地の確保および管理に 対する規制的手法が規定された条例であった)。また，これらの 3 条例により, 実際に指定されていた区域の箇所数は, まだ 37 箇所であり，すべてが 1999 年までに制定された条例によって指 定されたものであった（図一5）。このような結果となった理由と しては, 9 条例のうち 6 条例が 2000 年以降に制定されるなど, 全体として条例制定からの年数が浅いことに加え，住民の合意に よる計画の策定は時間がかかるもの ${ }^{15}$ であることが考えられる。 指定期間の継続性という視点からみた場合，特定区域は，1)時限 的区域，2)条件付永続的区域，3) その他の区域，の 3 つに分類さ れると考えられた ${ }^{16)}$ 。類型 $\mathrm{A} の$ 条例では，9 条例のうち，5 条例 が条件付永続的区域を, 2 条例がその他の区域を規定しており （表－5 ）, 地域住民や所有者の同意が得られる場合, 比較的長期 にわたり指定される可能性があると考えられた。

住民の発意に基づく計画は，とくにまちづくりの分野において， 実効性が高いことが示されている ${ }^{15)}$ 。また前述したように，特定 区域の指定ができるだけでなく，住民の参画により指定後の維持 管理の確保にも合意が得られ, 継続性が期待されるなど, 里地保 全に必要な側面に広く対応でき, 活用が期待される制度であると いえる。しかし, 実際の指定箇所数は極めて少なく, 活用の促進 が制度上の課題点として示唆された。

(ii) 類型 $\mathrm{B}$

類型 B の条例では，1970 年以降，わずかずつではあるが継続 して制定されてきた（図－4）。各条例と制定年の詳細を確認し たところ（表－6），1980 年代までと 1990 年以降の，大きく二 つの時期に区分されると考えられた。

1980 年代までの条例では, 「緑地保全」「緑化推進」の名称が 多くみられる。この時期は, 各自治体が宅地開発による環境の悪 化等の問題に対応するために, 都市内の樹林地や農地の量の確保 を目的とした施策を整備した時期であり ${ }^{177}$, 都市緑地の量的な確 保の必要性を背景に条例の制定がすすめられたと考えられる。

それに対し, 1990 年以降は, 新条例の制定之既存条例の全改 正，の二つの動きが確認された。新条例の特徴として「丘陵地の みどり」や「手賀沼斜面林」など, 特定の地域の保全を目的とし た条例や，「環境」関連の条例の制定があげられる。

前者は，地域の個別の問題に対応するものであり，後者は 1990 年代以降の環境概念の高次化 ${ }^{18}$ を背景に, 環境行政の一環と して二次的自然環境の保全に取組む動きを示すと考えられる。

既存条例の全改正については，1980 年代までに制定された 5 条例のうち 3 条例において行われた。改正は基本的に条例の位置 づけの見直しをはかるものであったが，その背景には斜面林や雑 木林などの，二次的自然環境保全の重要性の高まりがあった（表一 5 )。里地は，1994 年の環境基本計画における「里地自然地域」 に関して所定の政策が示されるなど，1990 年代半ばからその重 要性の認識が高まりをみせてきた。緑の量の確保を目的として始 まったこれらの条例が, 社会認識の変化に伴い, 二次的自然環境 の保全を意図したものへと変化してきたことが 示唆された。

また類型 B の条例のうち, 実際に特定区域 の指定が行われていた条例数を確認したところ, 11 条例のうち 8 条例において, 特定区域の指 定されており (図一 4), 実際に活用されるケー スが多いことが示された。更に類型 B により 指定されている区域の合計は 152 箇所であり, 類型 Aの 4 倍近くにのぼる（図一 6 )。この類 型の条例が活用の実態において里地保全行政に 
表 -6 類型 Bの条例の名称ならびに制定・全改正年

\begin{tabular}{|c|c|c|c|}
\hline \multicolumn{2}{|c|}{ 制定年 } & \multicolumn{2}{|c|}{ 条例名称 } \\
\hline \multirow[t]{8}{*}{ 1970-1979 } & 1972 我 & \multirow{2}{*}{\multicolumn{2}{|c|}{$\begin{array}{l}\text { 我孫子市緑地等の保全及ひ緑化の推准に関子る条例 } \\
\text { 調布市緑化条例 }\end{array}$}} \\
\hline & 1972 調布市緑化条例 & & \\
\hline & (1996) & \multicolumn{2}{|c|}{ (全改正後:調布市自然環境の保全等江関する条例) } \\
\hline & & \multirow{2}{*}{\multicolumn{2}{|c|}{ 新座市み异りの保全及び緑化の推准に関する条例 }} \\
\hline & (1991) & & (全改正後:新座市みとりりままちつくり条例) \\
\hline & & \multirow{2}{*}{\multicolumn{2}{|c|}{ 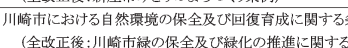 }} \\
\hline & (2000) & & \\
\hline & 1974 武 & \\
\hline $1980-1989$ & 1985 & \multicolumn{2}{|c|}{ 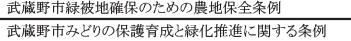 } \\
\hline $1990-1999$ & 1999 & \multicolumn{2}{|c|}{ 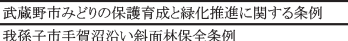 } \\
\hline $2000-2005$ & 2000 & \multicolumn{2}{|c|}{ 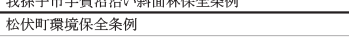 } \\
\hline & 2000 & \multicolumn{2}{|l|}{ 越谷市環境条例 } \\
\hline & 2001 & \multicolumn{2}{|l|}{ 逗子市み史艺条条例 } \\
\hline & 2005 & \multicolumn{2}{|c|}{ 八王子市市街地内丘陵地のみ民゙りの保全に関寸る条例 } \\
\hline 表- 5 & \multirow{3}{*}{\multicolumn{3}{|c|}{$\begin{array}{c}\text { 類型 } A / B \text { における区域指定の } \\
\text { 継続性に関する規定状況 } \\
\text { (単位:条例数) }\end{array}$}} \\
\hline & & & \\
\hline & & & \\
\hline \multirow{2}{*}{\multicolumn{2}{|c|}{$\begin{array}{l}\text { 特定区域の区分 } \\
\text { 時限的区域 }\end{array}$}} & 忿 $\quad$ 類型 $\mathrm{A}$ & 類型 $\mathrm{B}$ \\
\hline & & 1 & 7 \\
\hline \multicolumn{4}{|c|}{ 3年 } \\
\hline \multicolumn{4}{|c|}{ 5年 } \\
\hline \multirow{2}{*}{\multicolumn{4}{|c|}{$\begin{array}{c}5 \text { 年または } 10 \text { 年 } \\
10 \text { 年 }\end{array}$}} \\
\hline & \multicolumn{2}{|c|}{10 年 } & (1) \\
\hline \multicolumn{2}{|c|}{ 条件付永続的区域 } & 5 & 3 \\
\hline \multicolumn{2}{|c|}{ その他の区域 } & 2 & - \\
\hline \multicolumn{2}{|l|}{ 規定なし } & 1 & 1 \\
\hline
\end{tabular}

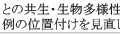
ものと考えられる。
全改正の背景

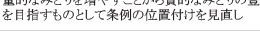

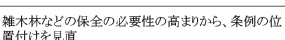

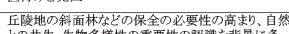

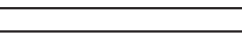
(20) 占める位置は大きい しかし，継続性に ついて確認したとこ ろ, 11 条例のうち 7 条例が時限的区域を 規定していた。さら に，それらの指定期 間についてみたところ, 3 年から 5 年の比較的短い期間を規定し たものが 5 条例であった。なお, 指定期間が時限的であっても, 買取請求が規定されている場合, 里地保全の効果に大きな影響を 与えると考えられる。ただし, 今回の対象条例において買取請求 を規定していた条例は類型 B の条件付永続的区域を規定した 2 条例のみであった。類型 B の条例は, 短期間の指定であること を明示するという傾向が読み取れる。一定行為の制限に加え, 管 理行為を規定している場合が多く, 比較的強い私権制限につなが るものであるため ${ }^{199}$, このような時限的な制度となっていると推 測され, 保全対象の長期的な保全が条例運用上の制度の課題点と して示唆された。

\section{5. まとめと今後の課題}

里地保全に関連する市町村条例は, その戦略において類型 A・ $\mathrm{B} ・ \mathrm{C}$ の 3 つの異なる特性を有するグループに分けられることが 示された。

類型 $\mathrm{A}$ は, 目的の複合化や一体的区域の指定の可能化により, 個別法令では対応しにくい問題や区域の一体的な保全という里地 の課題に, 地域住民の参加を促す制度を整備することで保全の実 現性を確保する戦略を有する条件整備型と考えられた。

類型 B は, 土地の確保と管理の両面からの保全という課題に対 し, 管理にまで配慮した行政主体の規制・誘導的手法により対応 するという戦略を有する，実質刘応型と考えられる。

類型 $\mathrm{C}$ は保全対象・担保手法に関する具体的な記述がみられ ない啓発型である点に特徴付けられた。

また類型 $\mathrm{A}$ 抢よび $\mathrm{B}$ の条例の条例について, 運用面において 異なる制度上の課題が示唆された。類型 $\mathrm{A}$ は, 地域住民の参画 により特定区域の指定を促すことを目標とする条例により構成さ れていたにもかかわらず，実際の指定状況は限られており，指定・ 活用の促進が課題として考えられた。また今回の結果からは得ら れていないが, 制度内容が住民に対し十分に周知されていないこ と, 行政側からの支援体制が十分でないこともその要因として考 えられ，今後の詳細な条例運用の実態把握が求められる。

それに対し, 類型 $\mathrm{B}$ は, 環境行政の一環としてあるいは地域 個別の問題への対応として新条例を制定する動き, 旧来の制度を 活用しながら条例自体の位置づけを全改正により変化させる動き, という二つの動向により, 里地保全に対応していることが示唆さ れた。制度が時限的である点が, 長期的な保全において問題であ り, 特定区域の継続的な指定確保のための手法の検討が求められ るほか, 区域の一体的な保全が課題として示された。
類型 $\mathrm{A}$ および $\mathrm{B}$ は, 里地の保全に異なる側面から対応し ており，おのおのに重要な役割を担うものと考えられる。ま た今回調查を行った自治体のうち，我孫子市のように両類型 の条例を制定している事例も確認された。このような両類型 の条例の活用により, 重要となる里山の管理による保全（類 型 B による対応）と，周辺地域の全体としての保全（類型 A による対応)，という異なる保全システムが関連付けられ， 里地保全の実現性が高められることも期待される。今後，市 町村における里地の保全において, 条例の重要性は増すもの 之考えられ，両類型の個別事例研究に基づくそれぞれの課題 点の解明が求められる。

謝辞

本研究をまとめるにあたり, 東京大学緑地創成学研究室の大久 保悟助手ならびに北川淑子氏をはじめとする研究室の皆様方に多 大なご指導, ご助力を賜りました。この場をお借りして厚く御礼 申し上げます。

\section{補注および引用文献}

1 ) 武内和彦 (2001)：二次的自然としての里地・里山：武内和彦・熟谷 いづみ・恒川篤史編「里山の環境学」：東京大学出版会, 東京, 1-9

2 ) Kobori, H. and Primack, R. B. (2003) : Participatory conservation approaches for Satoyama, the traditional forest and agricultural landscape of Japan. AMBIO 32, 307-311

3 ）深町加津枝（2000）：農村空間における生物相および景観の保全に関 する最近 10 年間の研究動向：ランドスケープ研究 63(3), 178-181

4 ) 大方潤一郎 (1999)：自治体総合土地利用計画の必要性と課題：季刊 日本不動産学会誌 13(4)，26-33

5 ）池邊このみ (2001)：市町村条例に基づいた土地利用の規制・誘導手 法の類型化に関する考察：農村計画学会誌 20,16-22

6 ) 成田頼明（1992）: 都市づくり条例の諸問題：第一法規, 東京, 24-26

7 ) 田中晃代・鳴海邦碩,・久隆浩 (1994)：まちづくり関連条例の展開と その意義：都市計画論文集 $29,685-690$

8 ）内海麻利・小林重敬（1998）：まちづくり条例の総合化動向に関する 研究：都市計画論文集 $33,541-546$

9 ）環境省（2003）：里地自然の保全方策策定調查報告書：自然環境保全 センター, 東京, $283 \mathrm{pp}$

10）例えば，二次的自然では農地，二次林，ふるさとの森，屋敷林などを， 二次的自然景観では農村景観，里山景観などを，規定している条例を 対象とした

11）三瓶由紀・武内和彦（2005）：東京圈における里地保全に関連する条 例の規定内容の把握 : ランドスケープ研究 67(4)

12）複数の特定区域が指定されている場合，生垣などを対象とした緑化推 進重点地区なども規定されていた。本論の主旨は，里地の保全に対し 各条例がどのような戦略を規定しているかを把握することにあり, こ れらの区域にはそれが反映されていないと考えられたため, 解析の対 象としていない。また二次的自然に関連する複数の特定区域を規定し ている条例も確認されたが，保全樹林と保全特別樹林のように，極め て類似した戦略が規定されている場合が多く，代表例の選択により条 例の規定内容の把握は可能であると考え，保全に関する特定区域を代 表例としてサンプルに採用した。

13）住民という用語は鹈々な解釈が可能であるが，本論では，地方自治法 第 10 条の定義に従い「市町村に住所を有する者」として扱い，特定 区域内の地権者は地域住民之記述することとする。

14）対象条例は改正されることもあるが，条例の制定年は今回の解析に使 用した二次的自然環境の保全に関連する代表的な保全区域を規定した 年とした

15）北村喜宣（1997）：環境行政過程と社会的意思決定：「自治体環境行 政法」：良書普及会, 東京, $123-237$

16）具体的には，時限的区域は，指定期間についての数值的な記述がある 場合, 条件付永続的区域は, 指定期間についての記述がなく指定解除 の申請がない限り区域指定が持続する場合，之の他の区域は，条例で は期間の決定過程のみを示し具体的な数字を規定しない場合について （例えば，地域住民による計画等の策定過程で指定期間に関する事項 を定めるものなど)，である。

17）平野㑆三（1997）：緑のまちづくり背策展開の系譜と展望：都市計画 $206,5-8$

18）内海麻利（1999）：まちづくり条例の類型とその動向：小林重敬編 「地方分権時代の街づくり条例」：学芸出版社, 東京, 44-53

19）北村喜宣（1999）:「環境政策法務の実践」：ぎょうせい, 東京, $292 \mathrm{pp}$ 